\title{
A PRESENÇA-AUSÊNCIA DOS ÁRABES E DE MUÇULMANOS' NOS PROCESSOS DE MODERNIZAÇÃO BRASILEIRA: A READEQUAÇÃO DOS MAPAS COLONIAIS
}

\author{
THE PRESENCE-ABSENCE OF ARAB-MUSLIMS IN THE \\ PROCESS OF BRAZILIAN MODERNIZATION: \\ READJUSTING COLONIAL MAPS
}

Alain Pascal Kaly*

Introdução

O surgimento do Islã no século VII marca uma virada nas estruturações da geopolítica ditada pelas forças político-religiosas (Judaísmo, Cristianismo e agora o Islamismo) e introduz na Europa Ibérica, via os mares Mediterrâneo e Vermelho, novos produtos alimentares, animais, aves, plantas, café, cana de açúcar, legumes e hortaliças, propiciando a completa reformulação das dietas alimentares, dos gostos, dos paladares, e da segurança alimentar no mundo ocidental. Os mesmos novos colonizadores introduzirem também novas estruturas urbanísticas, médicas, paisagís- ticas, culinárias, higiênicas e novos pensamentos filosóficos e técnicas agrícolas e de produção de café e de açúcar. Isso fez com que a cozinha islâmica (MASSIMO; MONTANARI, 2009) colocasse em contato diversas culturas árabo-muçulmanas (asiáticas, africanas e europeias) no mundo ibérico, proporcionando o surgimento de novas classes sociais, de identidades e também de fortes hierarquias socioeconômicas, intelectuais e de status decorrentes das capacidades de consumir certos produtos e alimentos e do acesso à terra desde o período medieval.

A domesticação da planta da cana-de -açúcar na Ásia e a sua industrialização

\footnotetext{
* Doutor em sociologia pela Universidade Federal Rural do Rio de Janeiro - UFRRJ (Seropédica/RJ/Brasil), professor de culturas e historias africanas no Departamento de História da UFRRJ. Coordenador do Núcleo de Pesquisas da África Contemporânea (NUPAC). Presidente da ONG VIDA Brasil/Salvador. papa1kaly@yahoo.fr 1. 0 grosso dos colonizadores do Mundo Ibérico era composto por brancos, judeus, pretos africanos e os africanos genericamente denominados de berberes convertidos ao Islã.
} 
no Marrocos, e a do café na Etiópia e suas introduções no mundo ibérico via a África do Norte inauguraram a agricultura intensiva, e lançaram as bases da produção do açúcar e de sua adoção na culinária e na farmacologia. A agricultura intensiva deu assim início à dessacralização dos alimentos e da terra, como também popularizou o acesso a novos alimentos, ao mesmo tempo em que lançou as bases das grandes propriedades de terras com necessidades de grande número de trabalhadores.

A introdução na Europa Ibérica das plantas da cana-de-açúcar e do café, e sobretudo de suas técnicas de plantio e de produção de açúcar e do café, constituíram as bases dos processos de colonização ("descobrimento" das Américas, tráfico e escravizações) que o mundo ocidental vai iniciar a partir do século XV e, concomitantemente, dos processos da modernização do próprio mundo ocidental e inclusive do que viria a ser o Brasil. Esse contexto permitiu o surgimento e a consolidação de uma gramática linguística, da colonização territorial e agronômica relacionada ao café e à cana-de-açúcar, que ia do plantio à produção do açúcar e de seus derivados até o café.

Este trabalho discute o papel dos árabes e muçulmanos (árabes, africanos islamizados, pérsios, turco-otomanos, mongóis...) nos processos coloniais das Américas e, sobretudo, como as técnicas de plantio de cana-de-açúcar e de produção do café, e as transformações das plantas em açúcar - iniciadas no Marrocos -, e dos grãos do café em café deram início à modernização do Brasil, inaugurando assim as lutas pela possessão de mais terras para atender às exigências da agricultura intensiva inventada pelos árabes-muçulmanos.

0 texto trata analiticamente dos complexos e longos processos coloniais e dos seus impactos nos processos da modernização e da consolidação do capitalismo, não só do mundo ocidental mas também das Américas séculos depois.

\section{0 Mar Mediterrâneo e o mundo ibérico: a ponte entre três continentes}

A cultura islâmica, contudo, não participa nesta mudança de percurso apenas em termos de alteridade negativa, mas ela própria fornece uma contribuição decisiva ao novo modelo gastronômico que está sendo elaborado na Europa medieval. Do Oriente Médio e da África chegam novas plantas e novas técnicas agricolas: a cana-de-açúcar, as frutas cítricas; hortaliças como as berinjelas e os espinafres; árabes e sarracenos são "mediadores", no Ocidente, do gosto oriental pelas especiarias e pelo agridoce, relançando modelos que a cultura gastronômica romana já havia experimentado, embora de maneira menos exclusiva. Também trazem para a Europa o cultivo e a cultura do arroz, na Sicília, e introduzem o uso da pasta seca, um gênero de consumo que também os hebreus estavam difundindo na Europa, destinado a um extraordinário sucesso, sobretudo no território italiano. (RIERA-MELIS, 2009, p. 14, tradução livre do autor).

0 algodão silvestre (a palavra deriva do árabe al-qoton) foi domesticado no vale do rio Indo no subcontinente indiano, em algum momento entre 2.300 e 1.760 a.C.; a habilidade dos indianos para tecer panos de algodão e tingir o tecido com cores resistentes foi logo descoberta pelos vizinhos, que começaram a enviar barcos e caravanas de camelos para comprar o tecido em troca de ouro, prata e pedras preciosas. Com a descoberta do vento de monção no século I d.C., navios oceânicos se somaram ao comércio de caravanas existentes com a Índia [...]. 
Ainda no ano 600, o algodão da Índia foi introduzido no Iraque, e de lá se espalhou para Síria, Chipre, Tunísia, Marrocos, Espanha e, finalmente, Egito. No século X, os árabes levaram o plantio do algodão até Portugal. (CHANDA, 2011, p. 125-126, tradução nossa)

Os árabes racionalizaram a cobrança de impostos, reestabelecerem a tolerância religiosa, construíram mesquitas, palácios e jardins fastidiosos e revalorizaram o mundo rural: eles renovaram e desenvolveram os sistemas de irrigação, introduziram novos cultivos tais como os agrumes, a cana-de-açúcar, o linho, o algodão, a seda, melancias e as tamareiras . Essa produção agrícola levou consigo inovações técnicas, notadamente no setor da transformação da cana-de-açúcar e da tecelagem da seda. Esses novos saber-fazeres foram mais tarde determinantes para a "modernização" da Europa e de suas colônias. [...].

0 século $\mathrm{X}$ marca o apogeu da civilização andaluza. Granada, que era sem dúvida a maior cidade da Europa, tornou-se o maior centro de sériciculture e das indústrias têxteis. 0 seu gênio arquitetural se materializou graças a formidáveis realizações, tais como a mesquita dos mercadores de algodão. A prosperidade da cidade provinha também das suas férteis planícies irrigadas, graças às técnicas de irrigação com roda que possibilitavam duas colheitas por ano, e do comércio transaariano do ouro dos impérios do Gana e depois do Mali. (GOODY, 2004, p. 38-39, tradução livre do autor)

Jack Goody, em L'Islam en Europe, publicado em 2004, salienta que o livro é o resultado das suas inquietações após do atentado do dia 11 de setembro de 2001. A partir daquele fatídico dia, segundo o autor, o Islã e os muçulmanos passaram a ser vistos e tratados de uma maneira muito mais visível, radical e violenta como sendo a "outra religião" e o muçulmano, como o "outro" a ser evitado, a ser vigiado constantemente para poder ser neutralizado antes que venha a cometer um atentado. A religião muçulmana passou a ser vista e tratada como sendo uma religião que materializa o atraso em relação aos valores democráticos tidos como típicos do mundo ocidental, e essa religião não faria parte do mundo "europeu" e nem da "civilização” ocidental. Essas atitudes e posturas político-ideológicas, midiáticas e culturais transformaram num mundo euro-americano o "árabe" e o muçulmano em prováveis terroristas ${ }^{2}$. É importante salientar que o atentado daquele dia inaugurou uma nova periodização, na historiografia ocidental, do mundo fortemente ocidentalizado: o mundo antes e depois do atentado. Isso proporcionou uma drástica mudança dos mapas da geopolítica militar mundial, midiática como também das novas ferramentas dos processos coloniais para se adequar ideologicamente aos mapas geográficos dos grupos "religiosos radicais" armados.

Quase 14 anos depois, outro atentado acontecido em Paris (cidade pilar dos direitos humanos), no dia 11 de janeiro de 2015, relançou novos debates sobre a "outra religião”, cujos praticantes são incapazes de se adequarem à civilização cristã e aos valores democráticos do respeito aos direitos humanos - valores estes exclusivamente ocidentais, segundo as crenças

2. Lila Abu-Lughod no seu artigo "As mulheres muçulmanas precisam realmente de salvação? Reflexões antropológicas sobre o relativismo cultural e seus outros" tece duras críticas ao mundo ocidental em relação ao uso do veio e da burka por mulheres muçulmanas. Ao focar analiticamente os debates sobre feminismo, gênero e religião, ela mostra a falta de compreensão e de respeito às práticas culturais no Afeganistão. 
político-ideológicas e culturais espalhadas cotidianamente pela mídia, como também pelos "grandes especialistas" do mundo ocidental. As mesmas crenças, sobretudo as jornalísticas, nos fazem acreditar que a presença da religião muçulmana nas terras "europeias" resulta dos movimentos migratórios de muçulmanos oriundos da África do Norte após a Segunda Guerra Mundial.

Contudo, a reflexão de Jacky Goody (2004, p. 21) nos revela que os processos da consolidação do que viria a ser a Europa foram constituídos conjuntamente com a presença do Islã e dos árabes e de muçulmanos na Europa, a partir do século VII.

No contexto do Cristianismo, durante o período romano, os judeus (e os cartagos) se espalharam por todo o império, da Itália à Espanha e à França, e além. 0 Cristianismo apareceu um pouco mais tarde, contudo ele consegue se impor somente depois da conversão de Constantino em 313, para depois se propagar a partir do seu berço romano.

A história do Islã na Europa inicia-se na realidade desde o surgimento da religião muçulmana no século VII, e sua expansão tem três grandes fases de penetração territorial. A religião monoteísta é uma das três maiores correntes religiosas originárias do Oriente Médio, que desde o início da nossa era marcaram a Europa com suas características.

Nascido três séculos depois, o Islã inicia sua expansão a partir do Magrebe desde o século VIII sob a impulsão dos árabes, depois chegando aos Bálcãs no século XIV levado pelos turcos e depois para a Europa setentrional pelos mongóis recentemente convertidos. Cada uma dessas fases de expansão contribuiu para fazer evoluir o pensamento oci- dental que começa a ter um acesso aos conhecimentos e à refınada civilização muçulmana e sobretudo à sua potência militar (tradução livre do autor nossa).

Das inúmeras informações contidas na reflexão de Jacky Goody, podemos afirmar que o Mar Mediterrâneo foi, ao longo da historia, um corredor de intensos intercâmbios de pessoas oriundas da Ásia, da África e da própria Europa, e ao mesmo tempo de ideias; práticas religiosas; filosofias; culturas; animais; técnicas culinárias, urbanísticas e paisagistas; etiquetas; tecnologias; agronômicos, plantas; como também das duas maiores religiões monoteístas: o Judaísmo e o Cristianismo. As duas religiões monoteístas ideologicamente teriam como berço de nascimento a Europa. Ora, fica claro que as duas religiões foram introduzidas na Europa via o Mar Mediterrâneo. Ao contrário do que aparenta, ideologicamente, ao longo da sua história, os europeus foram também adotando as práticas de higiene, religiosas, tecnológicas, culturais, filosóficas, de etiqueta, culinárias e de saberes por meio do contato com povos não europeus. Isso nos revela que, graças ao Mar Mediterrâneo, a Europa passa a se encontrar no cruzamento de intensos movimentos de intercâmbios de civilizações como já foi mencionado. Isso proporcionou à Europa Ibérica, segundo Jacky Goody, sobretudo, excelentes centros científicos e culturais (Renascimento italiano ${ }^{3}$ ) que muito contribuíram nas edificações do que viria a ser ideologicamente a característica da genialidade do mundo Ibérico e da Europa Ocidental a partir do século XV. Segundo Robin Blackburn

3. Não se pode apreender analiticamente o renascimento italiano sem tomar em conta as contribuições chinesas e árabo-muçulmanas (de árabes e de muçulmanos não árabes). 
(2003), isso inaugurou as estruturações dos mapas coloniais europeus, como também lançou as bases do surgimento do capital, do capitalismo e da modernidade ocidental ao mesmo tempo, inaugurando assim a geopolítica dos processos coloniais do mundo moderno.

Contudo, é de fundamental importância, segundo Moisés Espírito Santo (2006), cuja visão segue a mesma direção que a de Goody e Robin Blackburn, apontar a necessidade da reescritura dessa historiografia.

É necessário lembrar que foram os berberes do Marrocos quem invadiu a Península em 711, e não os árabes - como dizem a historiografia tradicional e os manuais escolares. Levados na corrente da ignorância geral, os autores dos manuais desconhecem os berberes, e iludidos pela ideologia islamista, favorecem a etnia árabe. Ora, os árabes islamistas simulam ignorar a identidade dos indígenas submetidos pela conquista. Segundo a ideologia islamista, as épocas que precederem o Islão foram as da treva ou ignorância (Jailiia). É indispensável para o Islão o esquecimento da cultura dos autóctones conquistados. A identidade dos berberes é ainda hoje vilipendiada pelo sistema magrebino e a sua língua proibida pelos árabes. 0 costume dos ibéricos privilegiar a cultura árabe e ignorar a dos berberes é um vestígio da antiga colonização em que as elites letradas se associavam ao Poder quando a plebe se distanciava dele. Para além deste alinhamento com os islamistas, há que acrescentar este efeito da ignorância vulgar: regra geral, os portugueses classificam de árabes todos os indivíduos e raças do Magrebe e do Médio Oriente (inclusivamente os de origem europeia, berbere, turca, persa, indiana e africana) porque confundem árabes, arabófonos e muçulmanos. (SANTO, 2006, p. 59)
É necessário destacar que os colonizadores do mundo ibérico não eram somente compostos dos chamados berberes, mas também de pretos do oeste africano islamizados (Soninké, Bambara, Fula...). Por isso, entendemos aqui por árabes muçulmanos os árabes e os muçulmanos não árabes, que constituíram a esmagadora maioria dos colonizadores do mundo ibérico. Contudo, é indispensável mencionar que até na própria África, os africanos muçulmanos de pele clara acreditam ideologicamente que são árabes.

A rápida penetração do Islã na Europa deveu-se às rotas comerciais que já interligavam as diversas partes da Ásia, da África e do mundo ibérico. Ora, segundo Goody (2004, p. 22):

0 Ocidente sempre passou sob o silêncio as influências muçulmanas tão antigas na sua cultura. Foram os historiadores que forjaram essa imagem da Europa forte, defensora das suas fronteiras e cuja civilização emana exclusivamente das heranças da Grécia, da Roma antiga e do Cristianismo.

Essa postura acadêmica vinha sendo criticada desde o século XIX por Anténor Firmin (L'égalité des races humaines, publicado em 1885), René Maran (Batouala), Sigmund Freud (Moisés e o monotéismo), Cheikh Anta Diop (Nations nègres et culture) e por Martin Bernal (Black Athena: les racines afro-asiatiques de la civilisation classique); visava e ainda visa a embranquecer e assepsiar totalmente a denominada civilização ocidental - a civilização que seria oriunda de povos exclusivamente brancos. Ora, os mares Mediterrâneo e Vermelho possibilitaram complexas e ricas hibridizações biológicas e culturais sem precedentes, decorrentes dos imbricados 
processos coloniais que nunca foram tratados como tais pela historiografia.

Uma postura ideológica encabeçada majoritariamente pelos historiadores, como bem salientou o pensador Jacky Goody, contribuiu e ainda contribui não só para invisibilizar e menosprezar a importância do papel desempenhado pelo corredor chamado Mar Mediterrâneo, mas também para negar a comunicabilidade cultural, agrícola, urbanística e civilizacional das duas margens do mesmo mar. Isso possibilita periferizar as contribuições dos continentes africano e asiático na civilização ocidental e universal durante longo período. Esse papel de corredor cultural desempenhado pelo Mar Mediterrâneo foi brilhantemente sintetizado por Léon L'Africain:

Eu, Hanssan filho de Mohamed - o pesador; eu, Jean-Léon de Médicis, circuncidado da mão de barbeiro e batizado da mão de um papa, sou nomeado atualmente de o "Africano”, mas à África não pertenço, nem à Europa e nem à Arábia. Chamam-me também o “Granadino”, o “Fassi”, o "Zayyati”, mas não venho de nenhum país, de nenhuma cidade, de nenhuma tribo. Sou filho do caminho, a minha patrícia é a caravana, e a minha vida a mais inesperada das travessias. [...]. Falo a língua árabe, a turca, o castelhano, a língua berbere, o hebraico, o latim e o italiano vulgar, pois todas as línguas, todas as preces me pertencem. Mas não pertenço a nenhuma. Eu só pertenço a Deus, à terra, e é para eles que um dia voltarei. (Léon L'AFRICAIN apud MAALOUF, 2014, p. 11, tradução nossa).

Léon L’Africain salienta com isso que, culturalmente, ele próprio é o somatório das riquezas culturais e civilizacionais que transitavam nas duas margens do Mar Mediterrâneo, que eram asiáticas, africa- nas e europeias. 0 mesmo Léon L'Africain nos informa que no corredor mediterrâneo circulavam e coabitavam os praticantes de diversas religiões, os falantes de diversas línguas e de diversas crenças religiosas. Contudo, a maior informação contida na sua reflexão consiste em dizer: eu sou linguisticamente, religiosamente e culturalmente o produto do respeito à diversidade. Isso fazia com que cada pessoa que transitava nas duas margens do mar fosse uma pessoa por natureza híbrida em todos os planos: religiosos, linguísticos, culturais e filosóficos. Isso coloca em xeque as crenças da pureza em diversos setores da vida humana. A mesma reflexão de Léon L'Africain clama pelo respeito às diversidades culturais, linguísticas, religiosas e populacionais por serem os pilares da estabilidade sociopolítica, étnica e religiosa das nações modernas.

As colocações de Léon L'Africain nos revelam que os quase oito séculos dos processos coloniais da Europa Ibérica pelos árabes muçulmanos lançaram as bases culturais, técnicas, linguísticas, religiosas, ideológicas, geográficas, mentais, filosóficas e tecnológicas das gramáticas dos mapas coloniais na própria Europa, cujas contribuições (LEWIS, 2010, XXIII) foram fundamentais na formação da mesma Europa e também do convívio de respeito entre as diferentes comunidades.

A batalha de Poitiers, que interceptou o Islã quando este contornava os Pirineus, em 732, e o martírio de Rolando e dos seus companheiros, quase meio século depois em Roncesvalles (Roncevaux), foram os acontecimentos de consolidação e de comemoração da identidade emergente do povo, chamado de "europense" pela primeira vez por um sacerdote espanhol desconhecido do século 
VIII. [...]. Sob essa perspectiva, a batalha de Poitiers e a canção de Rolando são momentos fundamentais na criação de uma Europa atrasada do ponto de vista econômico, balcanizada e fratricida que, ao se definir pela oposição ao Islã, transformou em virtudes a aristocracia hereditária, a intolerância religiosa persecutória, o partidarismo cultural e a guerra perpétua.

0 mesmo pensador, David Lewis (2010, p. 1), salienta que as conquistas territoriais do Islã a partir do século VII proporcionaram aos árabes as possibilidades para que realizassem uma das maiores revoluções em termos de estruturações do poder, da religião, da vida econômica, da arquitetura, do paisagismo, da cultura, em suma, inestimáveis contribuições para a história da humanidade: "tudo fez da Europa a Europa”. Contudo, é preciso sempre destacar que os chamados árabes, por Lewis, eram fortemente compostos por muçulmanos não árabes (pérsios, africanos de diversas regiões e tonalidades de pele, e brancos). Uma das maiores revoluções realizadas na Europa Ibérica durante o período da colonização árabo-muçulmana foi a introdução do plantio da cana-de-açúcar e do café, mais as técnicas de transformação dessas plantas em açúcar e em café. Isso viria a modificar drasticamente os paladares, a culinária e a alimentação europeias, mas sobretudo a segurança alimentar do mundo e o reordenamento dos mapas coloniais ao longo dos cinco séculos seguintes ${ }^{4}$. É importante entender aqui por Europa aquela que mais tarde lançaria as bases da modernidade ocidental a partir do século XV e também da ocidentalização do mundo via as diversas fases dos processos coloniais nas Américas, na África, na Ásia e no Pacífico, da geopolítica dos mapas dos processos coloniais, do capitalismo e do imperialismo.

Voltando a Goody, o mesmo pensador sustenta que a Europa, em vez de ser uma terra cristã, é, na realidade, um continente geograficamente situado no cruzamento do caminho de entrada de três religiões - todas originárias do Oriente Médio -, tendo mitologicamente um texto sagrado de origem comum (Judaísmo, Cristianismo e Islã).

Contudo, em relação aos medos visibilizados após o atentado do dia 11 de setembro de 2001 nos Estados Unidos, Goody afirma que a Europa sempre viu no Islã o seu maior inimigo, desde o século VIII, por ser, na realidade, o mais temido concorrente militar e cultural da Europa cristã. Goody (2004), Gillian Weiss (2014), Albert Hourani (1995), Amin Maalouf (2014, 1987) e Robert Mantran (1989) defendem que as contribuições dos árabes foram fundamentais nos planos culturais e na formação das identidades nacionais de alguns estados-nação - inclusive a França. Os árabes e não árabes convertidos ao Islã, que reintroduziram na Europa os clássicos gregos, também deixaram suas marcas na arquitetura e no paisagismo, nos jardins, nas praças públicas e nos banhos públicos das cidades do mundo ibérico. Segundo Goody, em termos científicos e de higiene, eles se encontravam bem à frente dos europeus.

A conquista da África do Norte e mais tarde o controle das rotas comerciais, conectando os impérios do Gana e mais tarde do Mali ao Oriente e ao mundo ibérico,

4. Ralph A. Austen e Woodruff D. Smith sustentam no artigo "Private tooth decay as public economic vitue: The slave-sugar triangle, consumerism, and european industrialization” que o consumo do açúcar e do café trouxe algumas das maiores desgraças em termo de doenças da modernidade. 
proporcionaram uma drástica mudança não só na geopolítica, mas também nos processos da colonização da Europa, com a introdução das técnicas agrícolas e da produção do açúcar e do café, iniciando assim os processos da modernização ocidental. Contudo, acredito insistir ser analiticamente mais seguro falar de árabes muçulmanos, pois entre os colonizadores do mundo ibérico a maior parte era composta por pretos e não pretos africanos (genericamente denominados de berberes) convertidos ao Islã, como também de pérsios e de brancos oriundos das terras conquistadas na Europa do Leste.

No trabalho reflexivo de Mamadou Diouf (2001), fica evidente que os povos islamizados dos impérios do Gana e do Mali foram sendo arrolados como militares para participar da colonização do mundo ibérico. As origens geográficas e étnicas dos almoravides possibilitam sustentar com maior certeza que os colonizadores do mundo ibérico não eram exclusivamente árabes - isso coloca em xeque a afirmação de que ser muçulmano era sinônimo de ser “árabe", independentemente da cor da pele e do local de origem. Apesar da numerosa presença de pretos africanos no mundo ibérico, a esmagadora maioria deles ocupava a mais baixa posição na escala social. Contudo, é importante mencionar que a presença de pretos africanos no mundo ibérico vem bem antes da chegada do europeu nas costas africanas a partir do século XV.

Quando a Andaluzia era muçulmana, sobretudo a partir do século XI, um corpo militar composto exclusivamente de soldados pretos - escravos - foi constituído em torno de 950 por Abderrahman na Naçir (literalmente o “conquistador"). [...]. No fundo, a imagem do preto na Espanha era similar à do Magrebe.
Comparativamente, as escravas-cantoras e as concubinas - brancas e pretas - encontravam um melhor tratamento nos lares dos soberanos e dos Emirs árabo-andaluzos. (MALEK CHEBEL, 2007, p. 38, tradução nossa)

0 mesmo pesquisador, Malek Chebel (2007), salienta que os mercadores árabes iam até as costas alemãs e à Bulgária para comprar escravos eslavos germânicos. Contudo, é importante destacar que o que Malek Chebel denominou de "melhores tratamentos" nos lares constitui uma tentativa de suavizar as brutalidades sexuais que faziam parte da vida cotidiana dessas mulheres. Contrariamente a Malek Chebel, Tidiane N'diaye (em Le génocide voilé, 2008) salienta que o tráfico de africanos pelos muçulmanos foi o mais longo e também o mais brutal por ter acrescentado a castração dos escravos às brutalidades que já assolavam-nos.

Gillian Weiss (2014), indo na mesma direção analítica que Goody, salienta que, algumas horas depois do atentado do dia 11 de setembro de 2001, iniciou-se nos Estados Unidos o trabalho de paralelismo entre a primeira guerra internacional da jovem república dos Estados Unidos entre 1801 e 1805, sob o comando de Thomas Jefferson - a "Guerra de Trípoli" contra a Líbia, em 1801-1805 -, e a luta contra a "Al Qaeda” sob o comando de George W. Bush Junior. A autora parte disso para colocar a seguinte pergunta: seria verdade que a Europa acaba de descobrir os muçulmanos e a religião islâmica? Ela foca sua análise sobre o paralelismo entre a constituição da identidade nacional francesa - decorrente das ambiguidades das relações mantidas pelos diferentes reis franceses, nos períodos entre 1550 e 1830 - com os muçulmanos das nações da África do Norte. Para 
apreender melhor a importância do Islã na estruturação da identidade nacional francesa, Gillian Weiss foca analiticamente a liberação dos escravos europeus católicos, brancos, por meio de compra. Segundo a autora, isso durou quase três séculos (de 1550 a 1830), o que nos mostra, mais uma vez, a importância do Mar Mediterrâneo na estruturação da chamada identidade nacional e da "grandeza" da França entre os séculos XVI e XIX.

Segundo ela, na primeira fase, esse processo de compra da liberdade de brancos católicos europeus escravizados pelos muçulmanos no norte da África era tratado como sendo uma caridade cristã do rei. Contudo, segundo Weiss, a recompra de escravizados europeus contribuiu fortemente para a consolidação do Estado francês e mais tarde tornara-se o pretexto usado para legitimar a colonização da região. Ora, até o século XVII, segundo a mesma pesquisadora, os reis franceses nunca tinham se preocupado com a vida dos seus súditos escravizados porque a maioria deles era composta por habitantes originários de regiões bem afastadas do poder central. Isso fez com que todos os organismos locais, religiosos e até laicos envolvidos nas articulações para a libertação dos seus conterrâneos estivessem extremamente seletivos sobre quem libertar em termos geográficos, profissionais e religiosos.

Depois os monarcas tomaram consciência dos perigos da escravidão; praticada pelos pretendidos infiéis, provocava um mal-estar à França, à sua prosperidade, à sua unidade nacional e à sua estabilidade social. Louis XIV não só começou a temer a perda de marinheiros, comerciantes e outros profissionais altamente qualificados, como também compartilhou as crenças das populações lo- cais: os escravos europeus estavam expostos a graves epidemias norte-africanas, notadamente a peste negra, a sodomia e o Islã. Foi somente entre os anos 1680 e 1690 que o rei teve os meios para proteger os seus súditos com maior eficácia. Ele preferiu pegar em armas do que no dinheiro exigido, e conseguiu repatriar a maioria dos católicos franceses escravizados em terras dos bárbaros muçulmanos, como também de outras nacionalidades. Mas, expurgando ao mesmo tempo o seu reino do cristianismo reformado, ele deixou voluntariamente os protestantes da França à servidão. Os reis podiam então escolher quem libertar das correntes muçulmanas, e isso teve consequências importantes sobre a noção do pertencimento à França. [...]. Consequentemente, a emancipação dos escravizados na África do Norte não constituía uma maneira de associar a França à liberdade: ela tornou-se cedo um método explícito para integrar os súditos das regiões geograficamente afastadas e ao mesmo tempo excluir os doentes e as almas desvirtuadas originárias, contudo do centro da França. (GILIAN WEISS, 2014, p. 7, tradução livre do autor)

As reflexões de Weiss, como também as de Murray Gordon (L'Esclavage dans Le monde árabe, VII-XXe Siècle, 1987) e de Jacques Heers (Les négriers en terres d'islam, VII-XVIe Siècle, 2011) nos possibilitam deplorar o silêncio ideológico no ensino da historiografia da Europa, nas universidades brasileiras, sobre a escravização de europeus brancos cristãos pelos africanos do norte durante séculos. E mais: como a recompra desses escravos brancos católicos, no caso da França, foi de fundamental importância para a construção da identidade nacional francesa, legitimando, assim, o papel do rei como sendo o protetor dos seus súditos. Ora, todos os escravos brancos 
comprados pelo rei foram enviados como engajados para as Antilhas e o Canadá. Outros foram forçosamente incorporados na marinha de guerra. Essas informações trazidas por Weiss, Gordon e Heers nos possibilitam sustentar, com maior tranquilidade, que os árabes muçulmanos não só lançaram o que viria a fornecer os pilares da modernidade do mundo ocidental com processos de colonização das Américas ("descobrimentos", agricultura da cana-de -açúcar, do café e do algodão, e as técnicas de produção do açúcar e do café), como também contribuiram para a formação das identidades nacionais. Ora, não se pode esquecer também que a mesma modernidade inaugurou automaticamente a era da civilização. Os excelentes trabalhos analíticos de Norbert Elias $(2011 ; 2013)$ não fazem referências aos impactos positivos (introdução do açúcar e do café no consumo das aristocracias) desse processo colonial na vida dos palácios aristocráticos europeus.

0 silêncio passou a contribuir bastante na periferização e invisibilização das contribuições da civilização árabo-muçulmana na formação da identidade nacional; também contribuiu ideologicamente ao legitimar indiretamente as diversas formas de racismo e preconceito que assolavam e ainda assolam a esmagadora maioria da população brasileira descendente de africanos por fazer acreditar que o negro africano foi o único a ser escravizado ao longo da história moderna da humanidade. Passou a fazer valer e ainda vale esta equação: negro africano = escravo. Ora, essa postura da historiografia brasileira contribui bastante para inculcar "inconscientemente" a colonização mental de diversas formas como complexo de inferioridade nos brasileiros descendentes em parte de africanos e, ao mesmo tempo, inculcar no brasileiro branco o complexo de superioridade, transformando assim, automaticamente, o ser branco em ser imbuído quase divinamente de prestígios e de poderes um cidadão nato como superior a outro.

Uma análise dos artigos que compõem o livro Branquidade: identidade branca e multiculturalismo, organizado por Vron Ware (2004), deixa transparecer, como bem salientou Peter (2004), a predominância da "branquidade" na historiografia dos Estados Unidos. É bom destacar que não foi somente o caso desse país, mas do mundo inteiro: isso deveu-se ao fato de que as periodizações historiográficas focam muito mais o século $\mathrm{XV}$, o que acabou fazendo do branco o cidadão universal como o responsável por iscar os não civilizados à condição de humano. Essa condição faz com que o branco seja, ou esteja, além do cidadão universal, o único a compor a mesa da Ceia dos Humanos e o único morador das zonas de conforto.

Apoiando-se nas reflexões de Victorien Lavou Zoungbo (2013), é possivel sustentar que, na realidade, a equação negro africano = escravo materializa-se na persistência do linchamento simbólico. Faz acreditar que os africanos são descendentes de "sub-humanos"; de "Zé-ninguéns". Peter Fryer (1993), em Aspects of British Black History, relata as lutas travadas dentro da sua casa para que os seus próprios filhos não tivessem mais vergonha de assumir serem descendentes de escravos. Ele argumenta que teve que convencer os seus $\mathrm{fi}_{1}$ lhos de que os seus ancestrais foram a base do capitalismo e das revoluções políticas, sociais, culturais e industriais ocorridas na própria Europa.

James (2012, p. 55) sustenta no seu instigante livro que os negros encabeçaram os movimentos revolucionários desde o inicio 
do tráfico e da escravização, desde a captura, nos navios negreiros, nos mundos das plantations e nos processos das lutas pelas independências das Américas: "A história revolucionária dos negros é rica, estimulante mas desconhecida." Segundo esse autor, sem a escravidão no Novo Mundo a burguesia francesa não teria conseguido acumular tantas riquezas que acabaram transformando-a em classe social incontornável para as mudanças sociopolíticas. De maneira enfática, James sustenta que sem os lucros do tráfico e da escravidão não teria havido a Revolução Francesa. Os negros não foram exclusivamente trabalhadores nas plantations, mas foram os pilares das revoluções sociopolíticas, pois suas lutas visavam à reconquista da dignidade humana e da liberdade e ao questionamento do sistema por meio das diversas formas de negação à subjugação. Os trabalhos de James (2012) e de Peter Linebaugh e Marcus rediker (2008) nos possibilitam afirmar enfaticamente que foram as lutas dos negros e dos brancos pobres que colocaram a América do norte nos trilhos da democracia se entendermos por democracia o alargamento das fronteiras das conquistas da dignidade humana.

Se a revolução do meio milhão protegeu a revolução francesa, ela estimulou também grandes revoluções pelo seu sucesso. Quando os revolucionários latino-americanos viram que um meio milhão de escravos podiam lutar e vencer, os revolucionários decidiram tomar em mão os projetos de levar suas colônias à independência. Bolivar, vencido e doente, procurou ajuda no Haiti. As autoridades haitianas o trataram, deram os recursos financeiros e armas que ele levou consigo no navio. Derrotado de novo, ele foge para o Haiti onde encontra a acolhida. E foi do Hai- ti que ele partiu para a sua última campanha militar que desemboca na independência dos cinco estados. (JAMES, 2012, p. 69)

As mudanças políticas, econômicas e sociais ocorridas no Brasil desde o final da década de 1980 continuam não sendo acompanhadas por mudanças dos currículos nas ciências humanas para se adequar às lutas e aos debates sobre a nação; à cidadania; ao acesso democrático à justiça social; aos direitos; às desigualdades sociais, políticas e culturais; aos privilégios e às "raças".

Ora, no caso da França foi a recompra da liberdade desses escravos, ao longo de vários séculos, que forneceu os meios ideológicos e políticos aos diferentes reis para consolidar as fronteiras da França, inventar e consolidar a identidade nacional francesa, ao mesmo tempo que fez da França um reino e depois uma República católica. Esse contexto nos obriga a afirmar que a França, enquanto metrópole, se constituiu geograficamente, religiosamente, administrativamente, politicamente e ideologicamente a partir dos efeitos de conflitos decorrentes das lutas pelo controle do comércio do Mar Mediterrâneo com os muçulmanos ao longo de vários séculos. E que a luta contra a escravização de brancos cristãos pelos muçulmanos na África do Norte constituir-se-á, mais tarde, como um pretexto ideológico legitimado para lançar as bases dos processos da colonização territorial da África do Norte. Portanto, a construção ideológica do "outro" (o muçulmano) e da "outra” religião (a muçulmana) desde o século XVI foi de fundamental importância para a edificação da França nos planos já destacados. Contudo, as mesmas autoridades francesas que estavam recomprando os seus súditos 
para livrá-los dos escravistas muçulmanos foram as que estavam iniciando o transbordamento de milhares de africanos para as Antilhas - processo este que vai durar até 1848 com a abolição da escravatura.

O declínio da escravidão no Mar Mediterrâneo a partir do século XVII coincidiu com a expansão da escravidão transatlântica. 0 número de franceses escravizados na África do norte diminui enquanto o das populações subsaarianas transportadas para as colônias francesas da América aumentava. (WEISS, 2014, p. 8).

Ideologicamente, para as autoridades, a escravização de europeus por um muçulmano proporcionava o declínio de sua humanização, enquanto a escravização de africanos por europeus contribuía para erigi-los da barbaridade e da condição de sub- humano à condição de humano. Neste caso, a escravização, como mais tarde a colonização territorial na África, desempenhou as funções civilizatórias por ter como missão a outorga da civilização aos africanos. Minimiza-se drasticamente o fato de que foi a escravização de africanos para as Américas que lançou (WILLIAMS, 2012; GILROY, 2001; BLACKBURN, 2003; REDIKER, 2011) as bases da modernidade ocidental, do capitalismo, das revoluções (sociais, políticas, culturais, industriais...) e mais tarde a ocidentalização do resto do mundo. E que foram os escravizados e seu trabalho, ao mesmo tempo, que fixaram as maiores e as mais profundas bases da modernidade no Brasil. Afırmar que não é possivel apreender a Revolução Francesa e o seu sucesso sem a escravidão de africanos para as Américas seria cometer a maior gafe histórica, por nunca se perguntar de onde vieram as riquezas (JAMES, 2012) da burguesia francesa.

\section{0 silêncio ideológico: os brancos nos porões}

É importante salientar que muitos dos brancos cuja liberdade fora comprada pelas autoridades imperiais francesas constituíram o grosso de franceses desembarcados nas colônias francesas das Américas (Antilhas, Canadá e Louisiana) na condição de engajados. Arnaud Bessière (2007) assinala que é necessário no caso francês diferenciar os engajados e os domésticos. Mesmo assim, o próprio Arnaud Bessiere destaca ser quase impossivel distinguir as duas categorias em termos de privações de liberdade e de brutalidades que os assolavam. Quer seja o engajado ou o doméstico, ambos desempenhavam as mesmas funções e também perdiam a liberdade - mas por um tempo bem determinado contrariamente ao escravo negro que será sempre visto e tratado como escravo como também a sua descendência. Entretanto, em termos hierárquicos, o doméstico dispunha de mais liberdade e recebia um salário estipulado, mesmo sendo muito baixo. 0 engajado, por sua vez, era quase um escravo branco nas mãos dos seus senhores durante toda a duração do contrato: ele trabalhava muito mais na agricultura, na conquista de novas terras ou tomando conta dos animais; seus maiores empregadores eram os proprietários de terras e as comunidades religiosas; o contrato estabelecido podia durar três anos ou mais - essa prática durou mais de um século.

Contrariamente ao trabalho de Arnaud Bessère (2007), que suaviza as relações entre os engajados brancos franceses e os seus senhores laicos e religiosos, Gillian Weiss salienta que as autoridades imperiais viram nessa prática de relações uma forma de livrarem-se definitivamente dos 
súditos indesejados: a viagem de ida às colônias - sem volta. Tratava-se, portanto, de franceses sutilmente expulsos do país. Gillian Weiss afirma que, apesar de perder completamente toda a sua liberdade, o engajado, no final do contrato, usava suas magras economias para comprar um pedaço de terra para recomeçar a sua vida. Assim, muitos jovens pobres e incapazes de pagar a viagem se alistavam como engajados. Uma vez nas Américas, trabalhavam nas plantations do senhor para reembolsar o valor da passagem. Muitos comandantes de navio traziam e vendiam o engajado para os fazendeiros quando chegavam ao seu destino. Mas qual era a grande diferença entre o engajado branco e o escravizado negro? 0 primeiro, ao finalizar o seu contrato, passava automaticamente a ser tratado como gente e os seus descendentes não herdavam a condição de engajado, enquanto o escravizado negro era o eterno escravo e os seus descendentes herdavam dos pais a condição desumanizante jurídica e ideológica de serem epidermicamente e mentalmente colonos. 0 escravizado negro e a sua descendência tinham a desumanização, a opressão, a marginalização e a impossibilidade jurídica e política do acesso à terra e às estruturas e aos meios necessários para refazer sua vida, ou seja, os elementos comuns da vida cotidiana. Contudo, a maior contribuição dos dois trabalhos consistiu em mostrar que muitos brancos franceses foram trazidos para as Américas na condição de "escravos", pois a esmagadora maioria da historiografia faz acreditar que somente os africanos chegaram às Américas na condição de escravos.

A escravidão no Caribe tem sido identificada com o negro de uma forma demasiado estreita. Com isso deu-se uma feição ra- cial ao que é basicamente um fenômeno econômico. A escravidão não nasceu do racismo; pelo contrário, o racismo foi consequência da escravidão. 0 trabalho forçado no Novo Mundo foi vermelho, branco, preto e amarelo; católico, protestante e pagão. [...]. 0 sucessor imediato do índio, porém, não foi o negro, e sim o branco pobre. Esses trabalhadores brancos eram de vários tipos. [...], entre 1654 e 1685, só de Bristol partiram 10 mil deles. Sobretudo para as Índias Ocidentais. Em 1685, os engajados brancos correspondiam a um sexto da população da Virgínia. Dois terços dos imigrantes da Pensilvânia no século XVIII eram engajados brancos; em quatro anos, só a Filadélfia recebeu 25 mil deles. Calcula-se que, durante o período colonial, mais de 250 mil pessoas pertenciam a essa categoria, e provavelmente correspondiam à metade de todos os imigrantes ingleses, a maioria se concentrando nas Colônias do Meio. (WILLIAMS, 2012; p. 378-379)

Eric Williams visa com essas informações a rejeitar e colocar em xeque os trabalhos de numerosos historiadores os quais fazem acreditar que os negros africanos foram os únicos escravizados a atravessar o Oceano Atlântico. Com a mesma reflexão, Eric Williams pretende desconstruir a equação já mencionada que faz do negro o único e eterno escravizado e escravizável da história moderna. 0 contexto de recompra de escravizados franceses no Mar Mediterrâneo, desde o século XVI, coloca em xeque também as constantes especulações ideológicas jornalísticas segundo as quais a França teve o seu maior contato com os muçulmanos com a chegada de "migrantes” econômicos do norte da África após a Segunda Guerra Mundial.

Os quase oito séculos de colonização do mundo ibérico pelos árabes muçulmanos 
transformaram o Mar Mediterrâneo (VERNET, 1985) em corredor que possibilitou intensos movimentos de intercâmbio de seres humanos, de culturas, de frutas, de técnicas e tecnologias, de ideias, e de práticas religiosas, artísticas e arquitetônicas. Ao mesmo tempo, foi incorporada a cultura do plantio de legumes e de especiarias que irá, ao longo dos processos coloniais, transformar drasticamente os gostos e os paladares do mundo cristão ibérico e depois do resto da Europa, inaugurando assim novas exigências gastronômicas. Apesar de emblemático, o livro escrito por Catherine Coquery-Vidrovitch e Eric Mesnard (2013) traz informações interessantíssimas sobre os impactos positivos das Cruzadas. Segundo Catherine, os soldados que voltaram vivos levaram consigo para a Europa legumes, frutas e especiarias que descobriram com aquele contato com os muçulmanos. Isso vai mudar drasticamente os costumes na alimentação, a gramática linguística culinária da Europa e - mais tarde - das Américas, como também o fazer agricultura nas zonas periurbanas. Ora, séculos depois, a procura por essas especiarias no mundo asiático vai consolidar o estreitamento das conexões entre o Oceano Índico e o Atlântico Sul. A guerra foi também outro fato social que possibilitou a colonização alimentar da Europa. Essas transformações gastronômicas levaram consigo as etiquetas de boas maneiras dentro dos palácios, em primeiro lugar, proporcionando assim profundas revoluções culturais de costumes na Europa. Norbert Elias (2011), em $O$ processo civilizador, ao analisar todo esse processo na Europa, coloca instigantes perguntas e questões, mas consegue, ao respondê-las, minimizar ou até silenciar as inestimáveis contribuições árabomuçulmanas na formação dos processos civilizadores de vários países europeus. Essas etiquetas fizeram também parte de práticas culturas trazidas pelos navios negreiros para as Américas presentes na vida cotidiana das grandes famílias no mundo das plantations.

Esse contexto gastronômico/econômico inaugurou um novo formato agrícola para atender às necessidades dos novos consumidores europeus, de produtos tal como o açúcar e o café: era a agricultura intensiva e extensiva exigindo numerosa mão de obra com diversas especializações. 0 novo formato, além de exigir grandes superfícies de terras, exigia também numerosos trabalhadores do plantio à transformação da cana-de-açúcar em açúcar, em rum e outros derivados.

Contudo, é de fundamental importância analítica voltar às contribuições culturais, econômicas, tecnológicas e sobretudo agrícolas desempenhadas pelo Mar Mediterrâneo para melhor apreender como os árabes muçulmanos tiveram fortes impactos na modernização do Brasil, e ao mesmo como muitos dos problemas que estão assolando uma grande parte da população decorreram disso: a secular detenção de grandes extensões de terras por poucos; a forte participação de produtos agrícolas no PIB; o peso político dos fazendeiros na vida política do país; e a secular luta dos descendentes de africanos e das populações indígenas para o acesso às terras. E mais: como as plantas (cana-de-açúcar, café, algodão e especiarias...) introduzidas por esses povos no mundo ibérico tornaram-se os pilares dos processos da modernidade do Brasil, como também da readequação dos mapas coloniais do mundo ibérico para as Américas do século XV até o final da primeira metade do século XIX. Os árabes muçulmanos, além de lançarem as bases do capi- 
talismo e da modernidade ocidental, deram importantes contribuições às gramáticas dos processos modernizadores das Américas "latinas" pós-independências sob o comando das elites brancas crioulas e dos brancos autoctonizados.

\section{Os pilares econômicos e culturais do No- vo Mundo}

Vinte anos depois, o vencedor de AL-Hudail estava no auge do seu poder, considerado por todos um dos mais experientes líderes militares do reino católico da Espanha. Desembarcou então do seu navio de guerra numa praia a milhares de quilômetros da sua terra natal e prendeu a correia do velho capacete que nunca trocava, embora tivesse ganhado dois de prata genuína. Agora usava uma barba, cuja cor ruiva provocava muitas brincadeiras irreverentes. Seus dois assistentes, já promovidos a capitães, o acompanhavam na missão.

A expedição viajou por várias semanas através de pântanos e florestas densas. Quando chegou a seu destino, o capitão foi saudado por representantes do governante local, vestidos com trajes nas mais belas e ousadas cores. Houve troca de presentes e a seguir o capitão foi levado até o palácio do rei.

A cidade era construída sobre água. Nem em sonhos o capitão podia imaginar um lugar como aquele. Os braços levavam as pessoas de um lado a outro da cidade.

- Sabe o nome deste lugar incrivel? - perguntou ao ajudante do barco quando chegaram ao palácio.

- Tenochtitlán é o nome da cidade e Montezuma é o rei.

- Esta construção custou muito dinheiro avaliou o capitão.

- É uma nação muito rica, capitão Cortés foi a resposta. 0 capitão sorriu. (TARIQ ALI, 2005, 280).
Tariq Ali, no seu livro Sombras da romãzeira (2005), ao analisar o esplendor e as contribuições do mundo árabo-muçulmano, finaliza o seu romance destacando as fortes conexões da história árabo-muçulmana no mundo ibérico com os processos coloniais da Espanha nas Américas.

Antoni Riera-Melis (2009, p. 21) afirma que foi desde o Neolítico que o Mar Mediterrâneo tornou-se o grande corredor no qual desfilaram e se cruzaram pessoas oriundas da Ásia, da África e da Europa. "Nas margens do velho mar, influenciando-se reciprocamente, conviveram línguas, religiões, estruturas de parentesco, sistemas alimentares, modelos políticos etc." 0 Mar Mediterrâneo possibilitou durante séculos a introdução na Europa de especiarias que iriam não só mudar drasticamente os paladares, os gostos alimentares de europeus e depois de grande parte das regiões do planeta, como obrigaria os povos a novos traçados do comércio mundial e da geopolítica, com o reordenamento do mapa-múndi focando o poder comercial e depois o militar. Isso inaugurou uma nova forma da globalização. Os processos coloniais do mundo ibérico lançaram os primeiros pilares dos mapas coloniais da geopolítica e das gramáticas da modernidade do mundo ocidental a partir do século XV com o início dos processos coloniais das Américas. Durante séculos, as lutas comerciais das potências marítimas europeias colonialistas (Portugal, Espanha, Inglaterra, Holanda, França...) giravam em torno do controle das rotas marítimas das especiarias oriundas da Ásia e introduzidas pelos árabes muçulmanos no mundo ibérico, primeiramente, e depois nas rotas do Novo Mundo. Isso leva a salientar a estreita relação histórica entre os mares Mediterrâneo e Vermelho, e o Oceano Atlântico. 
0 açúcar. A cana-de-açúcar (Saccharum officinarum) resulta de hibridação de diversas espécies selvagens que cresciam na Índia, no Sudeste asiático e na Indonésia. Inicialmente sua difusão se orientou em direção ao norte, através da Índia, até atingir, no final do primeiro milênio antes de Cristo, as regiões meridionais da China. Num segundo período, a cultura avança, com ritmo lento, em direção ao ocidente. Embora fosse conhecida por naturalistas gregos e romanos, a cana-de -açúcar não ultrapassou, na época clássica, as fronteiras da antiga Mesopotâmia. A conquista islâmica dos férteis vales do Tigre e do Eufrates, entre 633 e 642, imprimiu um ritmo mais veloz à sua expansão, e assim os muçulmanos assumiram o papel de seu agente difusor. Apareceu pela primeira vez na Síria e na Palestina, por volta de 700; uma década mais tarde, no Egito; por volta de 756, em AL -Andalus; e na Sicília, cerca de 878. (RIERAMELIS, 2009, p. 23)

0 cultivo da cana-de-açúcar desde os seus primórdios na África do norte e no mundo ibérico exigia um clima específico e muita mão de obra que foi mal paga ou escravizada, por se tratar de uma agricultura extensiva e intensiva. A produção de açúcar e dos seus derivados necessitou de instalações industriais de transformação e de especialistas, como bem salientou Antoni Riera-Melis (2009). A consolidação da agricultura da cana-de-açúcar e a produção do açúcar e dos seus derivados no mundo árabo-muçulmano (Marrocos, em primeiro lugar, no contexto da África ainda antes da sua introdução no mundo ibérico) demandou uma forte necessidade de trabalhadores. Isso acabou levando milhões de africanos na condição de escravos para a Ásia. A consolidação da agricultura de cana-de-açúcar foi acompanhada pela consolidação da escravidão de africanos e de não africanos, ao mesmo tempo, e de bases para lutas em prol da reconquista da dignidade humana.

No entanto, o cultivo da cana-de-açúcar no mundo árabo-muçulmano asiático inaugurou também os levantes orquestrados e levados a cabo pelos escravizados (africanos e não africanos) no século IX. Malek Chebel (2007, p. 129) aponta que o levante no século IX sob a direção dos trabalhadores escravizados (originários da África Oriental), em Bassora no Iraque, foi o maior e proporcionou drásticas mudanças nas relações sociais entre os escravizados e os seus senhores.

A insegurança de hoje em Bagdá e no resto do país lembra aquela que prevalecia no Baixo Iraq em Basra, a atual Bassorah, situada entre o rio Tigre e o rio Eufrates, nos tempos da revolta dos escravos negros, os Zandj, empregados pelos Abbassides na produção de sal na drenagem de mangrove para o cultivo da cana-de-açúcar. [...]. A realização daquela revolta, suas causas, suas consequências mobilizaram dezenas de pesquisadores de várias nacionalidades, na medida em que estes Zounouj tinham três características que ninguém encontrava em outros lugares: eram escravos, negros e revolucionários.

Segundo Malek Chebel (2007, p.130), os dirigentes do levante exigiam a liberdade, a igualdade e a não escravização de muçulmanos por outros muçulmanos, como exigia o Alcorão.

Em 871, quer dizer dois anos depois do inicio do levante, os escravizados conseguiram uma importante vitória. Este sucesso militar acabou atraindo para suas fileiras outros párias, todos aqueles que queriam aparecer co- 
meçaram secretamente a se identificar aos revolucionários. Foi o caso dos escravos urbanos, dos soldados negros de Bagdá e dos descendentes de escravos.

As promessas foram respeitadas e os revolucionários receberam terras e casas, e passaram a dominar militarmente o sul do Iraque. Contudo, para evitar outros movimentos, as autoridades reorganizaram uma contrarrevolução para liquidar os líderes negros. Eles foram derrotados após quinze anos de resistência. 0 cultivo da cana e a produção de açúcar foram acompanhados de intensos movimentos de revoltas e de revoluções por parte dos trabalhadores desde os seus primórdios. Os mesmos cenários de revoluções em nome da dignidade humana vão fazer parte dos mundos das plantações nas Américas a partir do século XVI.

Foi após essa revolução que o negro passou a ser sinônimo de escravo (negro = escravo) e conquistas, por ter demonstrado sua capacidade militar a ser fortemente usada como soldado nas guerras da expansão. 0 sucesso da revolta colocou em xeque um dos pilares das crenças ideológicas sobre a inferioridade do negro africano, pois só um ser humano pode ser um bom militar. Esse contexto colocou no mundo árabe os debates sobre a religião e a "raças". Ora, ao sustentar analiticamente que os debates sobre raças e suas hierarquizações teriam começado no século XIX denota-se um desconhecimento não só da historiografia universal, mas ao mesmo tempo da história da circulação das ideias e das técnicas nos imbricados processos coloniais entre os mundos árabo-muçulmanos e europeus, e da estreita conexão das historiografias entre os mares Mediterrâneo e Vermelho, e o Oceano Atlântico. Ao fazer isso, conscientemente ou não, elegemos a Europa como sendo "o eterno e o único centro" de todas as ideias e técnicas que cunharam as maiores revoluções políticas, sociais, culturais, religiosas e de costumes no mundo. Essa postura ideológica acadêmica foi brilhantemente sintetizada por Victorien Lavou Zoungbo (2013) em seu livro, com o seguinte título: Les Blancs de l'Histoire. Afrodescendance: parcours de représentation et constructions hégémoniques.

Nas Américas, as lutas dos escravizados individualmente e coletivamente fizeram também parte dos cenários dos mundos das plantations, e das lutas pela reconquista da dignidade humana. Ao se posicionar contra o tráfico e as brutalidades escravocrtas como bem salientou Eric Williams (2012) e Joseph E. Inikori (2002), os trabalhadores da plantation não seriam os primeiros proletários, como bem sugeriu sutilmente Sidney Mintz?

Esse capítulo da historiografia africana asiática vai se repetir quase nove séculos depois no mundo atlântico com a revolução orquestrada e levada a cabo pelos negros na Ilha de são Domingos, desembocando assim na independência do Haiti em 1804. Essa revolução haitiana influenciou bastante as independências latino-americanas, apoiando e financiando Simon Bolívar e outros líderes latino-americanos no mesmo período. As autoridades haitianas erigiram-se como os maiores defensores do respeito à dignidade humana e fervorosos opositores dos interesses desumanizadores do nascente sistema capitalista. Apesar da distância temporal e física, as duas revoluções compartilham dois fatos: 1) os revolucionários, como bem salientou Chebel (2007), eram escravizados negros cuja humanidade era sempre colocada em xeque; e 2) finalmente, o levante revolucionário 
questionava não só o sistema escravocrata e o desrespeito às recomendações do Alcorão sobre a não escravização de muçulmanos, as hierarquizações sociais e as desigualdades, como também derrubava os pilares da acumulação dos lucros.

Um meio milhão de rebeldes tinha morrido após a revolta que durou quatorze anos. A cabeça do chefe foi levada até Bagdá e exposta publicamente. A população foi convidada para meditar sobre a história daqueles bandidos que fizeram tremer Bagdá descontinuamente de 869 a 883 antes de serem decapitados. Foi esta mobilização coletiva que os crônicos denominaram de delírio coletivo. (CHEBEL, 2007, p. 131)

A decapitação e a exposição da cabeça do líder nos revelam como certas práticas no contexto dos processos coloniais foram sendo reproduzidas em outras regiões do mundo entres os séculos XV e XIX pelos novos governantes, independentemente da cor da pele e da religião, para materializar o poder das elites governantes. A exposição da cabeça decapitada de líderes que ousaram desafiar o sistema fez parte dos processos coloniais nas Américas e inclusive no Brasil (João José Reis, 2009, e Flávio dos Santos Gomes: Liberdade por um fio: história dos quilombos no Brasil), até a revolta de Canudos no estado da Bahia. A conquista e a consolidação dos processos coloniais sempre foram acompanhadas pela capacidade do total controle e da responsabilidade pela violência. Contudo, é fundamental salientar que os escravizados injetaram nos símbolos da superioridade da raça branca (THOMPSON, 2011) suas gramáticas linguísticas, religiosas, filosóficas, arquiteturais e tecnológicas, e seus gestos e linguagens ritualísticos...
Aimé Césaire (1994), no seu excelente livro, mostra como os processos coloniais nas Américas, na África e na Ásia foram se concretizando em brutais derramamentos de sangue. Os processos coloniais implicavam a desumanização e a descivilização de ambas as partes envolvidas. A concentração de terras nos processos coloniais ocorre em conjunto com a total desumanização e o deslocamento forçado de autóctones e de autoctonizados descendentes de trabalhadores migrantes forçados. A transferência dos mapas coloniais e de suas estruturas gramaticais para o Novo Mundo foi também acompanhada pelas exigências e características do mundo do cultivo do café, da cana-de-açúcar, do tabaco e do algodão, e de outras experiências da brutalidade colonial.

A história da geografia da cana-de -açúcar e do café no Brasil é ao mesmo tempo a história do início dos processos da colonização agrícola, dos genocídios das populações indígenas, dos deslocamentos forçados de milhões de africanos para a América portuguesa durante séculos, da concentração da terra, da sua transformação em capital e em patrimônio privado de famílias brancas (as sesmarias, lei da terra facilitando o acesso à terra quase exclusivamente à população branca), e o início da história da geografia dos processos da modernidade do que viria a ser o Brasil a partir de 1822. Os carros-chefes do processo da modernização do país, assim como as riquezas das elites crioulas e dos portugueses autoctonizados, provinham principalmente das fazendas de cana-de-açúcar, tabaço, de algodão e de café. Ora, grande parte da gramática linguística, do vocabulário técnico da produção do açúcar e do café, do paisagismo e da arquitetura está relacionada ao mundo árabo-muçulmano, pioneiro nas técnicas de plantio e produção 
de café e açúcar. É por isso que a apreensão historiográfica e cultural do Brasil e das Américas passa obrigatoriamente pelos debates sobre os processos coloniais da complexa e secular interculturalidade.

Contudo, no primeiro capítulo do seu clássico livro Casa-grande \&t senzala, Gilberto Freyre começa por destacar as capacidades mentais, sexuais, físicas e emocionais do português de se adaptar às duras realidades tropicais da África, Ásia e das Américas.

0 colonizador português do Brasil foi o primeiro dentre os colonizadores modernos a deslocar a base da colonização tropical da pura extração de riqueza mineral, vegetal ou animal - o couro, a prata, a madeira, o âmbar, o marfım - para a criação local de riqueza. Ainda que riqueza - a criada por eles sob a pressão das circunstâncias americanas - à custa do trabalho escravo: tocada, portanto, daquela perversão de instinto econômico que cedo desviou o português da atividade de produzir valores para explorá-los, transportá-los ou adquiri-los.

Semelhante deslocamento, embora imperfeitamente realizado, importou numa nova fase e num novo tipo de colonização: a "colônia de plantação", caracterizada pela base agrícola e pela permanência do colono na terra, em vez do seu fortuito contato com o meio e com a gente nativa. No Brasil iniciaram os portugueses a colonização em larga escala dos trópicos por uma técnica econômica e por uma política social inteiramente novas: apenas esboçadas nas ilhas subtropicais do Atlântico. A primeira: a utilização e o desenvolvimento de riqueza vegetal pelo capital e pelo esforço do particular; a agricultura; a sesmaria; a grande lavoura escravocrata. A segunda: o aproveitamento da gente nativa, principalmente da mulher, não só como ins- trumento de trabalho mas como elemento da formação da família. (FREYRE, 1987, p. 17)

Quando Freyre sustenta que o português foi o primeiro colonizador moderno a redirecionar todos os seus esforços para a criação de riqueza localmente, "esquece" de mencionar que o grosso dos portugueses chegando à colônia portuguesa das Américas estava fugindo da extrema pobreza e das instabilidades sociais, políticas e econômicas. Após a reconquista de Ceuta, os portugueses pretendiam conquistar as rotas comerciais do ouro que vinha dos impérios do Gana e depois do Mali. E, em termos de hierarquias sociais, os grupos sujeitos à migração forçada para escapar da pobreza eram compostos predominantemente pela ralé. É importante mencionar que esse contexto estava presente em todas as Américas. Contudo, contrariamente ao ensinado, a presença de africanos (os chamados berberes e os pretos) data dos tempos da colonização do mundo ibérico mais conhecido como sendo as invasões "árabes”.

Quem não veria nessa possibilidade de fuga a sua grande oportunidade para vir a se tornar alguém, uma pessoa, uma autoridade, um "nobre"? Ora, essas mesmas pessoas estavam erigindo social, ideológica e economicamente, assim como política e juridicamente como sendo os donos e os fundadores do novo país nas Américas: o Novo Mundo. Isso fará com que somente os seus descendentes venham a ter total controle sobre o funcionamento do novo país, a partir de 1822, como também sobre todo o seu funcionamento e as suas riquezas. Serão por direito nato os verdadeiros herdeiros. Assim, o Brasil nascente foi se consolidando como um país no qual o branco foi e é o Homem que o fez. Isso fez com que o branco tenha sido e continue 
sendo o cidadão pleno, e a "branquidade", a única referência para medir o grau da humanidade; das capacidades racionais; da beleza; da inteligência; do acesso à justiça social - em suma, de tudo aquilo a que um cidadão pleno teria direito. É por isso que concordamos com Albert Memmi (1973) quando ele afirma que o primeiro pilar da colonização é exclusivamente de ordem econômica. 0 mesmo pensador salienta que qualquer branco migrando para a nova colônia estará automaticamente à procura de facilidades e de enriquecimentos fáceis e rápidos. 0s "bravos" portugueses de Freyre estavam, na realidade, como bem salienta Memmi (1973), à procura de enriquecimentos fáceis os quais lhes outorgassem automaticamente condições materiais, emocionais, psicológicas e monetárias para que pudessem pleitear status honoríficos jamais possíveis na terra de origem devido ao seu "sangue" e à sua condição social. As riquezas acumuladas proporcionam o surgimento e a ostentação de títulos honoríficos somente autênticos e autenticados no Brasil de barões/baronesas; condes/condessas; viscondes/viscondessas; duques/duquesas; marqueses/marquesas. Esses títulos nobiliárquicos constituíam um tipo de certidão de nascimento no Brasil, que ao mesmo tempo possibilitavam a consolidação à autoctonização das famílias que viriam a ser as famílias tradicionais e donas do Brasil. A historiografia do Brasil gira basicamente em torno dessas famílias.

Seguindo a reflexão de Albert Memmi (1973, p. 39), fica claro que a colonização é ao mesmo tempo pai e mãe das desigualdades sociais, jurídicas e políticas - em termos de cidadania e dos privilégios. " 0 colonizador é um privilegiado e um privilegiado sem legitimidade, quer dizer um usurpador". A usurpação começa pelas melhores terras dos autóctones. 0 poder passava a ser legitimado pelo tamanho das terras e sobretudo pelos carimbos dos cartórios: os grandes proprietários exerciam forte controle sobre a vida política não só na colônia, mas também no parlamento das metrópoles, ao longo da estruturação do estado-nação. Esse contexto do poderio do mundo dos fazendeiros continua determinando grande parte das políticas internas do país no que diz respeito à reforma agrária para os pequenos produtores, aos índios e aos brasileiros negros do mundo rural. 0 país foi sendo erigido numa complexa estrutura de redes de dependência.

Para melhor apreender a estruturação dos privilégios no que diz respeito ao acesso à terra no Brasil, farei uso analítico da distinção feita por Albert Memmi. Ele afırma que há uma diferença entre o colonial, o colonizador e o colonialista. 0 primeiro seria o europeu vivendo na colônia, mas sem privilégios, cujas condições de vida eram às vezes iguais às dos colonizados. Esse europeu tem em termos de atitudes um pouco de respeito aos autóctones. "Eh bem, vamos dizer agora mesmo apesar da afırmação: o colonial assim defınido não existe, pois todos os brancos nas colônias são os privilegiados. 0 pequeno colonizador é geralmente solidário dos colonos e forte defensor dos privilégios coloniais." (Memmi, 1973, p. 40). No contexto das Américas e do Brasil, isso deixa muito pouca margem para os descendentes de escravizados e dos índios. A vida deles é feita de marginalização e de opressão sem saída, e até de constantes assassinatos no contexto dos índios como também dos lideres das comunidades quilombolas. As reflexões de Memmi nos fornecem elementos para refutar a tese freyriana da humanidade do processo colonial português nas Américas. A modernidade nasce com 
os processos de desumanização em todos os planos. Por isso, Aimé Césaire (2004, p. 81) afirma que o negro faz parte dos grupos humanos que sofreram as piores violências da história da humanidade.

Sim, constituímos uma verdadeira comunidade, mas sim uma comunidade de um tipo bem particular, reconhecível por ser, por ter sido, bem por ter se constituído em comunidade: primeiramente, uma comunidade vítima de opressão, uma comunidade vítima de exclusão imposta, uma comunidade vítima de discriminação profunda.

$\mathrm{Na}$ entrevista dada a Françoise Verges (2005, p. 23), Aimé Césaire sintetiza muito bem a condição do humano colonizado desumanizado pelos processos coloniais: "Quem sou-eu? Quem somos-nós? Quem somos-nós neste mundo Branco? Que problema!" Segunda questão, mas de ordem moral: "0 que tenho que fazer?" A terceira questão era de ordem metafísica: "0 que se pode esperar diante disso?” Essas perguntas colocadas por Cesaire, que faziam parte das preocupações cotidianas dos intelectuais do Movimento da Negritude, levam a uma única direção: para sobressair, precisamos lutar para a reconquista da nossa dignidade humana e da cidadania, e provocar a democratização do acesso à justiça social. Os processos coloniais fizerem do branco o único cidadão do mundo; ele é cidadão em qualquer lugar. Por isso que está à vontade em qualquer lugar. Isso foi consolidando o poder de dominação do homem branco. Ora, é preciso salientar que foram e continuam sendo as conquistas das lutas dos cidadãos das periferias a colocar ou recolocar os seus respectivos países nos trilhos da democracia, e da modernidade social e política. Se a modernidade econômica, industrial e tecnológica do Brasil foi construída graças aos lucros oriundos da plantation, foram os levantes e as revoltas dos negros marginalizados e oprimidos - e mais tarde as mobilizações dos seus descendentes, dos índios e das mulheres, e mais recentemente as dos homossexuais -, que contribuíram para colocar o país nos trilhos de modernidade política e social. Por isso que as lutas consistem em primeiro lugar em desconstruir intelectualmente, politicamente e ideologicamente as estruturas do poder de dominação masculina do branco ${ }^{5}$.

Retomando o mesmo Cesaire, um descendente de negros ou de índios no Brasil diante das brutalidades e da morte brutal que faziam parte de sua vida cotidiana e da falta de esperanças e perspectivas, poderiam ser feitas as mesmas perguntas diante da sua impossibilidade de acesso à terra quando esta tornou-se sinônimo de progresso, capital, desenvolvimento e modernidade, valores que requerem capacidades racionais inatas cujo único detentor era e continua sendo o branco. É importante mencionar aqui que o que parecerá ao leitor uma repetição consiste em dar maior destaque.

A reflexão de Freyre aponta, sem perceber, que, desde o século XVI, os bravos portugueses beneficiaram-se de estruturas do poder central legitimando a brutal expropriação de terras, a subjugação e os genocídios de povos indígenas, e depois o transbordamento (Gissant, 2009) de milhões de africanos para o sucesso da em-

5. Esta dominação masculina do branco dentro dos processos coloniais foi brilhantemente sintetizada por Aminata Dramane Traoré e Boubacar Boris Diop pelo título do livro deles: "La gloire des imposteurs. Lettres sur Le Mali et l'Afrique. 
preitada colonial portuguesa nas Américas. Contudo, as sesmarias constituíram a materialização do primeiro ato oficial de um rei a relacionar a doação da terra à raça e a uma classe social. Ao ler os excelentes trabalhos dos historiadores sobre as sesmarias, à primeira vista elas parecem tratarse de atos refletindo a demência de um rei. Contudo, o ato inaugurou a estreita relação entre as autoridades oficiais imperiais e depois as republicanas com as classes sociais das elites brancas autoctonizadas. Isso ficou claro na Lei das Terras de 1850. Essa lei mostra como o próprio Estado foi o próprio fiador e legitimador de quem deveria ou não ter o acesso às terras e de todos os incentivos econômicos e de proteção policial e jurídica em caso de confrontos com os deslegitimados pelo mesmo Estado por falta de racionalidade para contribuir ao desenvolvimento do Brasil com as produções agrícolas ${ }^{6}$. Isso lançou algumas das complexas bases das relações entre as classes aristocráticas agrícolas e de produtores rurais com as classes dos políticos do mundo urbano. É por isso que Albert Memmi (1973) sentencia que cada colonizador branco, independentemente da sua condição social, é sempre um fervoroso defensor do sistema colonial por beneficiar-se, em qualquer momento, da proteção policial e jurídica do Estado.

Contudo, essas relações passarão a se fortalecer e ao mesmo a transformar os grandes proprietários de terras em novas classes econômicas, políticas, militares e ideológicas incontornáveis para a estabilidade social, política e econômica do país. 0 século XIX, com a independência do país, inaugura uma nova fase colonial: a colonização interna sob as lideranças das poderosas classes sociais formadas por brancos crioulos e autoctonizados. Para melhor proteger os seus interesses e serem os únicos senhores da nova pátria, os legisladores passaram a promulgar leis que beneficiariam quase que exclusivamente as elites.

\section{0 novo formato do acesso à terra}

0 caso dos africanos resgatados do tráfico, como bem coloca Beatriz Galloti Manigonian (2005, p. 391), nos fornece elementos sobre a diferença entre os processos de independência nas Américas e os complexos processos de ser livre, e de ter liberdade e igualdade perante a lei. No entanto, o mesmo trabalho nos traz fundamentais informações sobre os cuidados que devemos tomar ao falar das independências nas Américas e sobre como os países foram sendo estruturados economicamente, em patrimônios públicos e privados, urbanisticamente, graças à mão de obra escrava: "ser juridicamente livre não garantia aos africanos livres a mobilidade espacial ou o direito à autodeterminação" ${ }^{7}$. A pergunta principal da autora é como explicar que quase 11.000 africanos livres tivessem que trabalhar em torno de 14 anos sob o regime escravocrata para os amigos do poder imperial e também para as instituições públicas.

0 que Mamigonian perdeu de vista foram os mecanismos mentais, jurídicos e políticos que estavam sendo elaborados para manter as hierarquias entre os brancos e os negros. Um segundo elemento que vai na mesma direção ou reforça e legiti-

6. Até hoje os grandes fazendeiros continuam beneficiando quase das mesmas proteções por parte do s estados da Federação como também da própria Federação.

7. Beatriz Galloti Mamigonian (2005, p. 391) 
ma essas hierarquias foi a recusa do acesso à terra para os africanos livres e libertos. Transformá-los em trabalhadores em regime escravocrata nas propriedades particulares e nas instituições públicas foi um dos meios sutis que o poder imperial encontrou para impossibilitar o acesso à terra aos africanos para que pudessem retomar dignamente a vida. Doar a terra ou instituir uma política reparatória para eles consistiria em colocar em pé de igualdade jurídica, política, emocional e mentalmente negros e brancos. A recusa do acesso à terra àqueles negros foi também um meio de marcar a diferença entre o negro e o branco, ainda que pobre. A recusa ao acesso à terra e à liberdade deles materializa como as autoridades políticas e sobretudo o Estado foi o principal fiador das estruturas proporcionadoras das hierarquizações entre os brasileiros e das desigualdades.

Um exame da experiência de trabalho dos africanos livres permitirá entrar na discussão das mudanças nas relações de trabalho no século XIX a partir da perspectiva de uma categoria de trabalhadores livres que não participou do mercado de trabalho assalariado. Mais de $80 \%$ dos africanos livres distribuídos para o serviço nos anos 1830 foram concedidos a particulares. Tal número incluiu 95\% das africanas e 75\% dos africanos livres distribuídos para o serviço aquele período. A experiência de trabalho dos africanos livres que serviram a concessionários privados estava muito relacionada com a escravidão no Rio de Janeiro oitocentista. (MAMIGONIAN, 2005, p. 393).

A recusa ou a invisibilização por uma corrente da historiografia brasileira da participação do negro no mercado de trabalho consistiria em negar automaticamente as capacidades racionais do negro, afirmar suas supostas incapacidades mentais e racionais de viver no mundo urbano, de efetuar tarefas exigindo o uso da racionalidade. 0 uso da racionalidade era e continua sendo, de uma maneira inata, um atributo do branco. Isso quer nos dizer, todavia, que a estruturação modernizadora do Brasil a partir de 1822 foi uma obra exclusiva da mão de obra dos migrantes brancos pobres, o que fica mais claro a partir desta colocação de Mamigonian (2005, p. 403):

As negociações de trabalho e ocupações de africanos livres mostram, no entanto, que eles eram tratados antes como escravos do que como trabalhadores livres. Nas maiores instituições públicas do Império, os africanos livres foram incorporados a grupos existentes de escravos da nação.

Entretanto, ter a análise com o foco exclusivamente nessa direção visa inadvertidamente a perder de vista que limitar o acesso à terra constituía as bases da ardilosa jogada das autoridades imperiais para manter o negro na condição de inferior em relação ao qualquer branco. A terra era e continua sendo sinônimo de poder, de capital, de investimento, um meio de barganha; a terra possibilita a reconquista da dignidade humana por proporcionar a liberdade. Ora, empregar aqueles africanos livres como trabalhadores assalariados implicava automaticamente lhes fornecer os meios para terem o acesso à terra e retomar a vida dignamente. Seria automaticamente aceitar e reconhecer que eles são humanos iguais a qualquer outro branco. Isso poderia também servir de "mau" exemplo aos outros negros "brasileiros” que precisavam sempre ser vigiados, disciplinados e controlados pelas autoridades de segurança. 
Se nos séculos XVI e XVII os reis doavam as terras sob a forma de sesmarias por serviços prestados, percebemos que no Brasil do século XIX pós-independente, para as novas autoridades imperiais, a doação era de seres humanos. Se, por um lado, o trabalho desses africanos livres participa da consolidação de patrimônios privados, sob o crivo das autoridades imperiais, por outro lado foram essas autoridades que criaram os mecanismos das desigualdades sociais, das hierarquias e dos privilégios secularizados, e a forte limitação de condições para que o negro tivesse que fincar todas as suas energias e capacidades para lutar contra os impactos negativos da desumanização.

Contudo, a crença de que as autoridades imperiais criaram mecanismos para dificultar o acesso à terra por parte dos negros tem maior sustentabilidade na medida em que, como bem coloca Mamigonian (2005, p. 407-408), muitos desses trabalhadores eram mandados para longe da cidade do Rio de Janeiro como trabalhadores forçados nas colônias militares e nos assentamentos indígenas. Mas o que seria um assentamento indígena? Uma reserva, como o que aconteceu nos Estados Unidos e no Canadá?

Dada a explosão econômica dos anos 1850 e do início dos anos 1860 e o investimento do governo imperial no desenvolvimento econômico em forma de subsídios, sustentação política ou envolvimento direto, seria razoável afirmar que o trabalho forçado de africanos livres contribuiu grandemente para o desenvolvimento econômico do país durante aquelas décadas.
Mamigonian parece ter como uma das suas preocupações comprovar que os africanos contribuíram na estruturação das bases do desenvolvimento do país/os africanos são pessoas. Isso deixa de lado um elemento fundamental nas estruturações das bases das desigualdades sociais e da marginalização do negro: a Lei de Terras de 1850. Mas, o que mais a pensadora perde de vista é o fato de que esses trabalhadores iriam consolidar, em grande parte, o patrimônio privado da burguesia brasileira nascente, como também o processo urbanístico do Rio de Janeiro e das grandes cidades do país. Ao longo de 66 anos (1822-1888), o trabalho escravo constituiu a base da modernização do novo país. Contudo, há uma coincidência entre os anos da explosão econômica nas décadas 1850 e 1860, e a Lei de Terras.

Desde o trabalho de Gilberto Freyre ( $\mathrm{Ca}$ sa-grande \&t senzala, 1987), os debates sobre a formação da identidade nacional continuam crescendo e ao mesmo tempo inaugurando pesquisas sobre as temáticas relacionadas ao acesso à terra, à violência contra as comunidades quilombolas e indígenas, à cidadania... No entanto, as seculares contribuições árabo-muçulmanas (árabes e não árabes convertidos ao Islã) na formação da identidade nacional e sobretudo na base da modernização Brasil continuam periféricas. Ora, a modernização e a modernidade foram possíveis graças à gramática linguística relacionada ao paisagismo, à agricultura da cana-de-açúcar, do café e do algodão - do plantio às suas transformações em produtos industrializados $^{8}$. Ao mesmo tempo, da in-

8. Peter Marks no seu livro "Portuguese" style and luso-african identity. Precolonial Senegambia , sixteenth-nineteenth centuries mostra que muitas construções das casas grandes eram técnicas arquitetônicas das sociedades diolas encontrados hoje no sul do Senegal. Robert Farris Thompson vai à mesma direção analítica. Ele salienta que as casas redondas encontradas nas Américas seriam técnicas arquitetônicas trazidas pelos escravizados do mundo Mandé na África Ocidental. 
trodução no Brasil do cultivo de especiarias que viriam a modificar drasticamente toda a sua gramática linguística culinária, como também as dietas, os costumes e as técnicas agrícolas periurbanas: a presença dos legumes e especiarias nas feiras semanais e nos supermercados atestam algumas das contribuições árabo-muçulmanas à modernidade brasileira. Outro produto alimentar da cesta básica introduzido no mundo ibérico pelos africanos foi o arroz, que depois será introduzido na América portuguesa pelos escravizados africanos. Segundo Coquery-Vidrovitch (2013), os primeiros grupos de escravos eram constituídos, em grande parte, de islamizados oriundos da África Ocidental. Foram eles que trouxeram os grãos e as técnicas agrícolas. É importante destacar que em muitas sociedades, o arroz é ao mesmo tempo alimento profano e sagrado.

Voltando à análise atenta da reflexão de Afrânio Garcia (2003), ele deixa transparecer como as intricadas relações sociais no mundo da Casa-grande \&t senzala vão constituir as bases das complexas hierarquizações da cidadania no Brasil moderno. 0 mesmo pensador defende que a plantation colonial teve fortes impactos na hierarquia das relações sociais do Brasil moderno. Contudo, a mesma plantation conectou muito cedo a colônia, e depois o Brasil, diretamente às rotas do comércio internacional graças às produções do café, do açúcar, do algodão e, mais tarde, do cacau, do sisal... Ao longo da história do Brasil, os grandes fazendeiros e usineiros eram fortemente dependentes do comércio internacional. Afrânio Garcia destaca o confisco dos espaços físicos, porém dá menos ênfase ao fato de como a plantation impõe a monocultura em detrimento das culturas de subsistência, confisca os direitos dos trabalhadores e é o símbolo das relações sociais feudais transplantadas da Europa Ibérica para o Brasil, no que diz respeito às relações sociais e às possibilidades de ascensão social fomentando legitimando assim as fortes desigualdades sociais e até jurídicas em termos de cidadamia.

Afrânio Garcia defende que as relações sociais predominantes no mundo urbano brasileiro moderno constituem, na realidade, o reflexo da socialização predominante no mundo rural. Contudo, no que nos interessa, defenderíamos que as relações sociais predominantes são as da Casa-grande Et senzala. Trata-se de uma sofisticada refeudalização mental, psicológica, emocional e epidérmica da sociedade brasileira. Faço uso deste formato estilístico de escrita para chamar a atenção sobre a readequação de um sistema de mapas mentais de relações sociais vigente na Europa e no Brasil, adotando o processo modernizador nos séculos XVIII e XIX das ideias das revoluções políticas e sociais. Isso fez e ainda faz com que o negro e o índio, em suma os não brancos tenham que fazer as perguntas colocadas pelos intelectuais do Movimento da Negritude nos anos 1930 sobre o lugar do negro no mundo tido como sendo exclusivamente do branco. Afrânio Garcia (2003) não percebeu o papel outorgado à agricultura familiar. Ora, quando se fala da agricultura familiar, estamos automaticamente nos referindo aos brancos "pequenos" no mundo rural - ela possibilita ideologicamente uma desfeudalização dos mapas mentais das relações sociais entre os "grandes" e os "pequenos" brancos. A desfeudalização implica a quebra da rigidez nas relações sociais entre os "pequenos" brancos e os "grandes" brancos porque, em caso de perigo dos negros e dos índios; em suma dos não brancos, os dois grupos precisam se juntar para defender os 
interesses da branquidade/ o poder de dominação masculina do branco. Isso possibilita reduzir o grande fosso em termos de cidadania entre os mesmos grupos socioétnicos. Foi essa política de desfeudalização dos mapas mentais das relações sociais, linguísticas, emocionais e epidérmicas das pessoas do mesmo grupo ético (os brancos) que possibilitou defender e "convencer" que as desigualdades no Brasil são de ordem social e não racial.

Ora, os brasileiros não brancos passaram e ainda passam a viver das vontades paternalistas dos políticos, transformando assim o negro e o índio em eternos "filhos" de um/a político/a e de um partido político. Assim, os favores tornam-se impagáveis. Os negros e os índios continuam sendo os cidadãos tutelados por um político e um partido independentemente de ser da direita ou da esquerda.

É por isso que a camada social dos pequenos brancos se beneficia de fortes incentivos financeiros (como os empréstimos facilitados dos bancos), jurídicos, políticos, comerciais e técnicos. Por isso, no que diz respeito às políticas públicas voltadas ao mundo rural, os negros das terras quilombolas e extravistas não entram no cômputo dos esforços das políticas públicas dos governos municipais, estaduais e federais porque, ao longo da história do que é hoje o Brasil, a terra era e continua a ser sinônimo de desenvolvimento, de progresso, de modernidade e de civilidade. E é por isso que ela era incentivada a ser ocupada e explorada por aqueles que sabem de sua importância: os grandes e pequenos brancos. Neste caso, o acesso à terra tornou-se um dos elementos medidores do grau da humanidade/racionalidade.

0 acesso à terra fornece elementos indispensáveis para apreender a estrutura- ção das zonas de privilégios, ou seja, sobre como o ser branco é ser um ser humano detentor inato de poder e privilégios. Os migrantes europeus trazidos para trabalhar nas plantations entre a segunda metade do século XIX e as primeiras décadas do século seguinte não deveriam ser exclusivamente apreendidos analiticamente sob a ótica da política de embranquecimento, mas também como sendo as camadas que possibilitaram uma sofisticada refeudalização/quebra da rigidez das relações sociais entre os membros da mesma "etnia" no Brasil moderno mas ao mesmo tempo constituintes das barreiras de contenção entre as camadas sociais perigosas moral, eticamente, econômica e racionalmente. Esses migrantes vão constituir a forte muralha de proteção contra as pretensões de justiça social dos negros. Para melhor incentivá-los a manter a solidez da contenção da muralha, esses brancos vão beneficiar-se por parte do Estado de incentivos para que possam fincar os seus sonhos e ao mesmo tempo legitimar as crenças ideológicas da superioridade do branco aos não brancos. Ao negro, a possibilidade do acesso à terra passa em grande parte pelas perícias dos antropólogos tendo que confirmar a autenticidade e a coerência dos relatos dos ocupantes das terras quilombolas. Vale destacar a forte coincidência entre as lutas por direito à terra por parte dos brasileiros não brancos (negros e índios) e a criação de órgãos federais para falar em nome deles: o Incra e a Funai.

0 excelente trabalho de Mohammed Ennaji (2007) sobre poder e religião no mundo árabe nos fornece mais elementos do mundo árabo-muçulmano nas complexas relações entre poder e cidadania. Ennaji (2007) sustenta que a desconstrução do Estado no mundo árabe passa inevitavelmente pela 
dessacralização do poder do Estado. A sacralização do poder (ver na autoridade política um representante moral de Deus na terra) implica automaticamente que todas as relações sociais e políticas entre os governantes e os cidadãos eram e continuam a ser a mola propulsora das relações de submissão, dependência, clientelismo, paternalismo, condescendência e favor.

Contrariamente à crença mais difundida, estamos persuadidos de que a escravidão foi um aspecto determinante das relações sociais no mundo árabo-muçulmano. Pelo fato de não tê-la abordada na mesma perspectiva no mundo ocidental, antigo ou moderno - notadamente a partir do seu papel primordial na produção de riquezas -, a escravidão revela ser de uma importância tão pertinente ao approche das relações sociais quanto no que diz respeito à análise do poder (ENNAJI, 2007, p. 16, tradução nossa)

As reflexões de Ennaji nos possibilitam sustentar que, além das contribuições árabo-muçulmanas já referidas, continua prevalecendo ideológica, mentalmente e de uma maneira sutil, politicamente, que a salvação do não branco passa automaticamente pela vontade do branco. Se no mundo árabo-muçulmano a religião passa a ser o elemento determinante nas relações entre as autoridades (o rei, o príncipe...) e os seus cidadãos, no caso brasileiro, no lugar da religião, foi a branquidade que assumiu papel determinante. No mundo muçulmano, o ex-escravo e os seus descendentes serão sempre tratados como seres humanos precários, enquanto no Brasil os não brancos são tratados como eternos cidadãos precários, periféricos e periferizados, devendo sempre depender da bondade das autoridades políticas. Será que uma das consequências dos quase oito séculos de colonização do mundo ibérico pelos árabes muçulmanos não teriam sido marcas indeléveis na estruturação das complexas hierarquias da cidadania no Brasil? Os mapas mentais, jurídicos, emocionais, linguísticos e psicológicos das relações sociais baseadas em tratamentos desumanizantes não seriam resultantes das junções de dois formatos coloniais: o árabo-muçulmano e o ocidental?

\section{Considerações Finais}

Os processos de modernização do mundo ocidental e depois das Américas e inclusive do Brasil obrigam os debates sócio-históricos a priorizar as conexões estabelecidas entre os mares Mediterrâneo e Vermelho, e depois o mundo atlântico. Ao longo de séculos, os dois mares jogaram pontes ligando Ásia, África e Europa. Ao longo de quase oito séculos, numerosos e intensos intercâmbios de pessoas, culturas, plantas, legumes, técnicas, especiarias, tecnologias, saberes, práticas religiosas e gramáticas linguísticas relacionadas às técnicas de produção do café, do açúcar e dos seus derivados e do algodão, assim como às técnicas pastoris, transitaram entre as margens. Além disso, as concepções do mundo e das relações sociais foram também transplantadas. Esses patrimônios culturais, civilizacionais, comerciais, linguísticos, técnicos, tecnológicos e das engenharias urbanas, periurbanas e sociais serviram como pilares dos processos coloniais das Américas, inaugurando, ao mesmo tempo, as bases da modernidade ocidental, do capitalismo, da ocidentalização do mundo e também da modernização das Américas, inclusive do Brasil. 0 levante de Salvador (denominado por João José Reis 
de a Revolta dos Malês), cuja organização fez da escrita árabe seu meio de comunicação, nos revela de novo a participação de afro-muçulmanos nas lutas pela reconquista da dignidade humana e pela humanização das relações sociais.

Os debates sobre a fábula da formação da identidade nacional sempre destacaram e ainda continuam destacando as "três raças”, passando sob silêncio as inestimáveis contribuições do mundo árabo-muçulmano não só na formação da identidade como também nos processos da modernidade do Brasil. A complexidade das hierarquizações da cidadania e das relações entre os governantes e os seus cidadãos continuam seguindo normas e atitudes estabelecidas durante os períodos da escravidão: o senhor branco-católico e o escravo negro não católico. A modernidade e a modernização/ civilidade continuam baseando-se nos ditames dos moldes dos países desenvolvidos. 0 Brasil está desempenhando o papel de um país periférico, grande fornecedor de matérias-primas. Desde os donos das plantations no período colonial passando pelos usineiros e pelos grandes brancos dos agronegócios, a modernidade implicava e ainda implica vender para o comércio internacional com fortes incentivos do Estado. Essas relações sociais nos levam a sustentar que, em termos de cidadania, no Brasil as relações sociais de dependência do cidadão não branco com os representantes do Estado são parecidas com as do contexto do mundo árabo-muçulmano. Nos dois contextos sociopolíticos, as antigas relações escravocratas continuam determinando o acesso aos benefícios outorgados ao cidadão pleno. As contribuições do mundo árabo-muçulmano estão ainda fortemente presentes nos mapas das relações socais quando se trata da cidadania.

\section{Referências}

ALI, T. Sombras da romãzeira. Rio de Janeiro. São Paulo: Record, 2005.

AMSELLE, J. L.; M'BOKOLO, E. Au coeur de l'ethnie: ethnie, tribalisme et Etat en Afrique. Paris: La Découverte, 1999.

BERNAL, M. B. Athena: les raciness afro-asiatiques de la civilisation classique. Paris: PUF, 1999.

BESSIERE, A. L. A domesticité dans la colonie Laurentienne au XVIIE siècle et au début du XVIIIE siecle (1640-1710). Montreal: Université du Quebec / Paris IV - Sorbonne. Disponivel em: <http://www.archipel.uqam.ca/650/1/D1612. pdf $>$. Acesso em: 27 jan. 2015.

BLACKBURN, R. A construção do escravismo no Novo Mundo: do barroco ao moderno, 14921800. Rio de Janeiro: Record, 2003.

CÉSAIRE, A. Non à l'humiliation. Paris: Actes Sud, 2012.

Discours sur le colonialisme. Paris:

Présence Africaine, 2004.

Nègre je suis, nègre je resterai: entretien avec Françoise Vergès. Paris: Albin Michel, 2005.

CHANDA, N. Sem fronteira: os comerciantes, missionários, aventureiros e soldados que moldaram a globalização. Rio de Janeiro: Record, 2011.

CHEBEL, M. L'esclavage em terre d'Islam. Paris: Fayard, 2007.

COQUERY-VIDROVITCH, C.; MESMARD, E. Etre esclave: Afrique-Amériques, Xve-XIXe. Siècle. Paris: La Découverte, 2013.

ELIAS, N. 0 processo civilizador: uma história dos costumes. 2. ed. Rio de Janeiro: Zahar, 2011. .Formação do estado e civilização. Rio de Janeiro, Zahar, 2013. 
ENNAJI, M. Le sujet et le mamelouk: esclavage, pouvoir et religion dans le monde arabe. Paris: Mil et une nuits/Fayard, 2007.

FLORENTINO, M. (Org.). Tráfico, cativeiro e liberdade: Rio de Janeiro - séculos XVII-XIX. Rio de Janeiro: Civilização Brasileira, 2005.

FREYRE, G. Casa grande \&t senzala. Rio de Janeiro: José Olympio, 1987.

FRYER, P. Aspects of British black history. London: Index Books, 1993.

GARCIA, A. Sociologia rural no Brasil: entre escravos do passado e parceiros do futuro. Revista Sociologias, Porto Alegre, v. 5, n. 10, p. 154189, jul./dez. 2003. Disponível em: http://www. redalyc.org/articulo.oa?id=86819564006. Acesso em: 29 set.2015.

GILROY, P. 0 Atlântico negro. Rio de Janeiro: Ed 34, 2001.

GLISSANT, E. La philosophie de la relation. Poésie en étendue. Paris, Gallimard, 2009.

G00DY, J. L'Islam en Europe: histoire, échanges, conflits. Paris: La Découverte, 2001.

GORDON, M. L'esclavage dans le monde arabe - VII - XXe Siècle. Paris: Robert Laffont, 1987.

GRUZINSKI, S. Que horas são... lá, no outro lado? América e o Islã no limiar da época moderna. São Paulo: Autentica, 2012.

HEERS, J. Les négriers em terres d'Islam. VII ${ }^{\mathrm{e}}$ XVIe. Siècle. Paris: Perrin, 2011.

HENRQUES, Isabel Castro. Os africanos em Portugal. História e memória, séculos XV-XXI. Lisboa, Paris, UNESCO, 2011.

HOURANI, A. 0 pensamento árabe na era liberal: 1798-1930. São Paulo: Companhia das Letras, 2005.

Uma história dos povos árabes. São Paulo: Companhia das Letras, 1995.

INIKORI, J. E. African and the industrial revolution in England: Study in international trade and economic development. New York: Cambridge Press, 2002.
JAMES, C. L. R. Sur la question noire: sur la question noire aux Etats Unis, 1935-1967. Paris: Syllepse, 2012.

LEWIS, B. A descoberta da Europa pelo Islã. São Paulo, Perspectiva, 2010.

MAALOUF, A. Léon l'Africain. Paris: Librairie Générale Française, 2014.

. Les croisades vues par les arabes. Paris: Jean Claude Lattès, 1983.

MAMIGONIAN, B. G. Revisitando a "transição para o trabalho livre": a experiência dos africanos livres. In: FLORENTINO, M.(Org.). Tráfico, cativeiro e liberdade. Rio de Janeiro, séculos XVII-XIX. Rio de Janeiro: Civilização Brasileira, 2005. P.389-417.

MANTRAN, R. (Org.). Histoire de l'empire ottoman. Paris: Fayard, 1989.

MASSIMO, M. (Org.). 0 mundo na cozinha: história, identidades, trocas. São Paulo: Senac, 2009.

MARAN, R. B. Paris: Magnard, 2002.

MEMMI, A. Portrait du colonisé précédé de protrait du colonisateur et d'une préface de Jean Paul Sartre. Paris: Payot, 1973.

MINTZ, S. 0 poder amargo do açúcar: produtores escravizados, consumidores proletarizados. Recife, Edufpe, 2003.

MOUMOU, J. (Org.). Sociétés marronnes des Amériques: mémoires, patrimoines, identités et histoire du XVII ${ }^{\mathrm{e}}$ au $\mathrm{XX}^{\mathrm{e}}$ siècles. Guayanes Française: IBIS Rouge, 2015.

NDIAYE, P. La question noire: essai sur une minorité française. Paris: Calmann-Lévy, 2008.

PEARSON, M. N. Port cities and intruders. The Swahili coast, India, and Portugal in the early modern era. Baltimore and London, The Johns Hopkins University Press, 1998.

RACHLEF, P. "Branquidade": seu lugar na historiografia da raça e da classe nos Estados Unidos. In: Branquidade. Identidade branca e multiculturalismo. Rio de janeiro, Garamond/UCAM, 2004.p.97-114. 
REIS, J. J.; GOMES, F. S.; CARVALHO, M. J. M. 0 Alufá Rufino: tráfico, escravidão e liberdade no Atlântico negro (1822 -1853). São Paulo: Companhia das Letras, 2010.

REIS. J. J. Rebelião escrava no Brasil: a história do levante dos Malês em 1835. Edição revista e ampliada. São Paulo: Companhia das Letras, 2009.

RIBEIRO, D. 0 povo brasileiro. A formação e o sentido do Brasil. São Paulo, 2013.

RIERA-MELIS, A. 0 Mediterrâneo, crisol de tradições alimentares: a herança islâmica na culinária catalã medieval. In: MASSIMO, M. (Org.). 0 mundo na cozinha: História, identidades, trocas. São Paulo: Senac, 2009.

RISLER, J. C. La civilisation arabe. Paris: Payot, 1962. RODRIGUES, N. Os africanos no Brasil. São Paulo: Companhia Ed. Nacional, 1982.

SANTO, M. E. Os mouros fatimidas e as aparições de Fátima. Lisboa, Assírio \&t Alvim, 2006.

THOMPSON, R. F. Flash of the spirit: arte e filosofia africana e afro-americana. São Paulo: Museu Afro Brasil, 2011.

VERGES, F. La mémoire enchaînée: questions sur l'esclavage. Paris: Hacehtte, 2006.

Abolir l'esclavage : une utopie coloniale: les ambiguités d'une politique humanitaire. Paris: Albin Michel, 2001.

VERNET, J. Ce que la culture doit aux arabes d'Espagne. Paris: Actes Sud, 1985.

WARE, V.(Org.). Branquidade: identidade branca e multiculturalismo. Rio de Janeiro: Garamond/ Afro Candido Mendes, 2004.

WEISS, G. Captifs et corsaires: L'identité française et l'esclavage en Méditerranée. Toulouse: Anarcharsis, 2014.

WILLIAMS, E. Capitalismo e escravidão: São Paulo: Companhia das Letras, 2012.

ZOUNGBO, V. L. Les blancs de l'histoire afrodescendance: parcours de représentation et constructions hégémoniques. Perpignan/France: PUP, 2013. 
RESUMO

A introdução na Europa Ibérica das plantas de cana-de-açúcar e do café e de suas técnicas de plantio e de produção constituíram as bases dos processos coloniais ("descobrimentos", tráfico e transbordamento de milhões de africanos para a Europa e as Américas) do mundo ocidental a partir do século XV. Concomitantemente, constituíram também os processos da modernização do mundo ocidental. Nossa reflexão visa a destacar o importante papel desempenhado pelos árabes muçulmanos nos processos coloniais das Américas e, em especial, como as técnicas de plantio de cana-de-açúcar e de café, e as transformações das plantas em açúcar e dos grãos do café em café deram início à modernização do Brasil, inaugurando assim as lutas pela possessão de mais terras para atender às exigências da agricultura intensiva inventada pelos árabes.

\section{PALAVRAS-CHAVE}

Colonização. Árabes muçulmanos. Mundo ibérico. Modernidade.

\section{ABSTRACT}

The introduction into Iberian Europe of sugarcane and coffee, and above all the agricultural techniques for growing and producing these crops constituted the basis for Western colonial processes ("discoveries" and the Atlantic slave trade that brought millions of Africans to Europe and the Americas), starting in the fifteenth century, also sparking the process of modernization of the Western world. This paper seeks to highlight the fundamental roles played by Arab-Muslims in the colonial processes of the Americas, showing, above all, that farming techniques for sugar cane and coffee and the post-harvest processing of these crops sparked the modernization of Brazil, also inaugurating struggles over land acquisition in order to meet the needs of intensive agriculture invented by the Arabs.

\section{KEYWORDS}

Colonization. Arab-Muslims. Iberian World. Modernity and land access. 
